\title{
The influence of personality trait and demographics on financial decision making among Generation $Y$
}

\author{
Joyce K.H. Nga and Leong Ken Yien
}

Joyce K.H. Nga is based at Taylor's Business School, Taylor's University, Selangor Darul Ehsan, Malaysia. Leong Ken Yien is based at Sunway University Business School, Sunway University, Selangor Darul Ehsan, Malaysia.

\begin{abstract}
Purpose - Financial planning is important in promoting the social well-being of a nation. Without proper financial planning, individuals may be ill-prepared in coping with the escalating cost of living, medical costs as well as enjoying their desired quality of life. However, financial decision making is not always made in a rational manner. This study aims to investigate the influence of personality traits, genders and course majors on decision making dimensions of risk aversion, cognitive biases and socially responsible investing (SRI) criteria among Generation Y undergraduates.
\end{abstract}

Design/methodology/approach - The study utilizes a sample of undergraduates from a business school in Klang Valley, Malaysia. The study adapts the Big 5 personality scales from McCrae and Costa. The scales for the financial decision making dimensions, namely risk aversion, cognitive biases and SRI constructs, were developed for this study based on concepts developed from the extant literature. The validity and reliability of the scales were tested using exploratory factor analysis and Cronbach's alpha respectively. Hypotheses were tested using multiple linear regressions, t-tests and ANOVA methods.

Findings - Conscientiousness, openness and agreeableness were found to have a significant influence on risk aversion, cognitive biases and SRI respectively. Gender and course majors taken were not significant in financial decision making.

Research limitations/implications - Future research should extend this to different cohorts of individuals including working adults and retirees. The mediating influences of personality and moderating influences of demographic factors such as education level, age and religiousity should also be explored to better target potential investors and fulfill their financial goals.

Practical implications - Awareness of the influence of specific personality traits in financial decision making would help financial planners tailor products more effectively to cater for the understanding and lifestyle of the younger generation. There may also be a need in the future for business schools to introduce courses on behavioural finance in their curriculum.

Originality/value - Studies on financial planning have more often focused on rational aspects of financial decision making rather than on personality dimensions. This study bridges the gap by investigating the influence of the Big 5 personality traits in financial decision making. The study also posits that the influence of personality traits is more significant than demographic factors in financial decision making.

Keywords Business education, Generation Y, Financial planning, Consumer behaviour, Decision making, Students, Malaysia

Paper type Research paper

\section{Introduction}

A PriceWaterhouseCoopers (2009) study of 346 Generation Y Malaysian respondents found that 65 per cent of them expect to rely on personal investments and savings to fund their retirement. This may be attributed to the lack of a social safety net in Malaysia. Contributions to the Employee Provident Fund (EPF) are perceived to be inadequate in supporting their desired quality of life. It has also been found that 14 per cent of EPF members exhausted their savings within three years, 50 per cent within five years and 70 per cent within ten years 
after retirement (Ali, 2011). The Malaysian government has agreed to increase the minimum retirement age from 55 to 60 from 1 July 2013.

Many Malaysians are ill-prepared for retirement. Only 34 per cent of them have provided for a retirement fund (Hunt, 2009). Many Malaysians invest their money in low interest yielding banking accounts which is not sufficient to support the escalating cost of living in view of inflation. As such, more active financial planning is necessary. Failure to make proper financial decisions may hamper social welfare and Malaysia's goal to achieve the high income status by 2020 .

In coping with ambiguity and uncertainty, investors often rely on cognitive biases in making financial decisions (Keil et al., 2007). Behavioural finance suggests that human decision making involves a combination of cognitive and affective dimensions (Olsen, 2010). Personal values, emotions, personality traits and societal influence influence investors' subjective perception of reality in financial decision making. Research has found that these factors may be more relevant in explaining share price movements than economic factors alone (Smith and Harvey, 2011; Shiller, 2002).

However, not much is known about the financial decision making behaviours of Malaysian Generation $Y$ undergraduates as potential investors. This study addresses this gap in literature by focusing on the following research questions:

$R Q 1$. What is the influence of the Big 5 personality trait dimensions (extroversion, openness, neuroticism, agreeableness and conscientiousness) on financial decision dimensions (risk aversion, cognitive biases and socially responsible investment)?

$R Q 2$. What are the influences of demographic factors (gender and majors) on financial decision making dimensions?

There were a total of 314 respondents who responded to our survey questionnaire. The data was analyzed using the Multiple Regression method, ANOVA and T-Tests. Validity and reliability was tested using Exploratory Factor Analysis and Cronbach's Alpha respectively.

This study has implication on promoting better communication and understanding of clients in financial planning as well as in banking relationships and operations. It also recommends that Behavioural Finance modules be integrated into Finance Degree programs in Malaysia.

\section{Financial decision making dimensions}

Economic and finance theories assume individuals are rational and optimal utility seekers. However, events such as the Dutch Tulipmania, Black October 1929 and the Financial Crisis 2007-2009 indicate that these assumptions do not always hold in reality (Landberg, 2003). Fear and greed fuel bubbles in financial markets (Landberg, 2003). Behavioural finance holds that human decision making can be explained from cognitive, emotional and social dimensions (DeBondt et al., 2010). This study investigates financial decision making from the perspective of employment of risk aversion, cognitive biases and socially responsible investing criteria.

\section{Risk aversion}

Financial decision making is often made in an environment of uncertainty. Perception of risks are influenced by factors such as the degree of trust towards information sources, level of individual knowledge, market volatility and the regulatory provisions (Diacon, 2004). Individuals also differ in their risk capacities and tolerance (Bosner and Lakehal-Ayat, 2008). Risk capacity is linked to an individuals' level of income, family background and age. On the other hand, risk tolerance is related to the attitudes and beliefs about money. Furnham (1996) developed a taxonomy of monetary orientations ranging from conservative types (misers), impulsive (spendthrifts), value seekers (bargainers), speculators (gamblers) and wealth endowed (tycoons) reflecting a spectrum of risk tolerance/aversion of individuals. Speculators are willing to bear higher financial risk which is beneficial in providing 
information and liquidity to capital markets (Angel and McCabe, 2010). However, speculation resembles gambling when the high stakes assumed do not commensurate the returns.

The love for money has been found to be correlated with risk tolerance and unethical behaviour among students in USA (Tang et al., 2008). Risk aversion and materialism have also been found to moderate the relationship between financial numeracy and financial decision outcomes (Huhmann and McQuitty, 2009).

In Economics, the expected utility theory (EUT) operates on the premise that individuals are rational utility maximizes. The EUT assumes that individual preference towards risk remains constant regardless of the current wealth endowment (Kahneman, 2003). Individuals are assumed to be risk neutral and devoid of emotions (Ackert et al., 2003; Kahneman, 2003; Rabin and Thaler, 2001). However, Prospect Theory holds that individuals are more risk averse in dealing with potential gains than losses (Rabin and Thaler, 2001; Kahneman and Tversky, 1979). Risk aversion causes a dispositional effect whereby investors tend to let go of winning shares too early and hold on to loosing stocks for too long.

In reality, emotions form an integral part of financial decision making. Individuals have been found to be more optimistic and willing to assume greater risk after a succession of winning gambles, and vice versa for losses (Ackert et al., 2003). Overconfidence occurs when individuals develop the illusion of control over certain familiar attributes which leads them to place excess emphasis on their own knowledge and capabilities (DeBondt et al., 2008; Keil et al., 2007). In financial decisions, overconfidence can occur due to familiarity towards a particular company or financial instrument and/or past successes (Barber and Odean, 1999). Overconfident individuals tend to ignore negative feedback and/or problems (Keil et al., 2007). The unrealistic optimism that develops often leads to excessive risk taking and herding behaviour (Baker and Nofsinger, 2002). In contrast, regret aversion causes individuals to hold on to loosing stocks in anticipation of a better payoff (Miller, 1999).

\section{Cognitive biases}

The theory of bounded rationality posits that within an environment where cognitive capacity and time are limited, humans make decisions that are only partially rational (Herbert, 2000). Individuals tend to adopt a "satisficing" rather than optimizing behaviour in deriving their utility and related search costs (Hoy and Tarter, 2010; Olsen, 1998). Heuristics are used to simplify the task at hand and in coping with uncertainty (Olsen, 1998). For instance, experts often rely on benchmarks and rules of thumb (Smith, 1999a). Studies have found that heuristics do not necessarily lead to inferior judgments (Gigerenzer and Gaissmaier, 2011).

Cognitive biases in financial decision making can be explained in terms of framing, selection and overconfidence (Keil et al., 2007). Framing biases occur when individuals orient their thoughts on certain held beliefs which do not fully represent reality (Chong and Druckman, 2007). Framing bias causes outcomes to be influenced by the way alternative choices are presented to the decision maker (Kahneman, 2003). The perception of reality constraints an individual's financial judgment (Olsen, 2010; Statman, 1999).

Selection biases occur when individuals filter and place greater importance on information that is significant to them. These biases occur in the form of anchoring, availability and representativeness biases (Thaler and Sustein, 2009; DeBondt et al., 2008). Anchoring bias occur when individuals fixate their attention on specific information for instance, performance benchmarks or targeting a buying price for a share. Availability bias involves the likelihood that individuals will place greatest weight on the most readily recalled information. This could spark fear and cause over reaction of markets to sensational news releases, e.g. Enron and Worldcom fraud debacle leading to panic selling. Representative biases occur when individuals employ stereotypes or draw conclusions from small samples (Baker and Nofsinger, 2002) and leading them to misclassify investments as good investments (Nilsson, 2008). 
As society and investors become more sophisticated greater importance is being placed on how companies derive their profits. Investors are subscribing to the view that unethical companies cannot sustain shareholders' value (Harrington, 2003). Increasingly, non-financial criteria are being used to screen for corporate social performance such as environmental sustainability, community involvement, workforce and corporate governance practices. In practice, it is difficult to establish the link between corporate social performance and financial performance. Investors with expressive decision frames would more likely prefer SRIs than those with financial decision frames (Glac, 2009). Besides this, investors' pro-social attitudes and their perceived effectiveness as consumers to produce change have been found to influence their intention to subscribe to SRIs (Nilsson, 2008). Compared to conventional investors, socially responsible investors evaluate apply more criteria in establishing ethical investments (McLachlan and Gardner, 2004).

Generation $Y$ is known to be internet savvy and are more social conscious compared to previous generations. The internet and social media have created a tribal sense of community among them which seeks greater authenticity in corporate social responsibility. This cohort also believe that they can make the future better via their lifestyle and employment choices (Williams et al., 2010; PriceWaterhouseCoopers, 2009). This study investigates the intention to adopt SRI criteria into financial decision making by Generation $Y$ undergraduates.

\section{Personality dimensions}

Personality traits are a combination of distinguishing emotional, cognitive and motivational characteristics which influence the way individuals respond to his/her environment and make decisions (Dole and Schroeder, 2001; Smith, 1999a). Individual personality traits have been found to influence spending, investment management and risk tolerance (Krishnan and Beena, 2009; Mayfield et al., 2008; Smith, 1999a).

The Myer-Briggs type indicator (MBTI) classifies personality into four domains namely judging versus perceiving, sensing versus intuition, thinking versus feeling and extrovert versus introvert (Leary et al., 2009; Smith, 1999a). The MBTI is based on Carl Jung's Psychological Types in 1921. The MBTI describes personality as preferences in the way individuals make decisions rather than personal characteristics. Following MBTI, the big five factor model comprising extraversion, openness, agreeableness, conscientiousness and neuroticism was developed (McCrae and Costa, 1997). This study adopts the big five factor model in investigating financial decision making.

\section{Extraversion}

An extrovert is externally oriented and would be at ease socializing in a large crowd (Leary et al., 2009). Extraversion is also associated with gregariousness, high excitement, assertiveness, optimism and ambitiousness (Robie et al., 2005; McCrae and Costa, 1997).

Extraversion has been found to exert a significant influence on hindsight bias in investment decisions (Sadi et al., 2011). Extraversion promotes a positive outlook which impacts one's assessment of the probability of success and may result in overconfidence in financial decision making (Keil et al., 2007). Optimism also causes extraverts to prefer short term investments. Thus, we advance the following:

H1(a)-1(c). Extraversion has a significant influence on (a) risk aversion, (b) cognitive biases and (c) SRI.

\section{Openness}

Openness describes the fascination towards novelty, aesthetics and new ideas (Gunkel et al., 2010; McCrae and Costa, 1997). Individuals possessing this trait are imaginative, creative, broadminded and resourceful (Martins, 2002). They are also flexible in their 
decision making approach (Robie et al. 2005). However, they may sometimes appear to fantasize and rely on emotions in their actions (McCrae and Costa, 1997).

In a study of Tehran investors, openness has been found to exert a positive influence on hindsight and availability bias (Sadi et al., 2011). Materialism has been found to exert a positive influence on tangible sensation seeking but negatively related with openness to new experiences (Troisi et al., 2006). Research has also found that openness exerts a positive influence on long-term investments in business school US undergraduates (Mayfield et al., 2008).

Based on the above, individuals who possess the openness trait may perceive risk differently. They may also be more willing to consider other qualitative criteria such as SRI in financial decision making. Thus, we posit the following:

H2(a)-2(c). Openness exerts a significant influence on (a) risk aversion, (b) cognitive biases and (c) SRI.

\section{Agreeableness}

Agreeableness reflects a person's friendliness, warmness and cooperativeness in social interactions (McCrae and Costa, 1997). Highly agreeable individuals are forgiving, tender hearted, good natured and are well accepted by their peers (Martins, 2002). They tend to be altruistic and compliant to social norms. As such, they are more direct and modest in their decision making approach (McCrae and Costa, 1997). It is likely that agreeable individuals place high emphasis on social criteria and consensus in financial decision making and thus we suggest the following:

H3(a) to 3(c). Agreeableness exerts a significant influence on (a) risk aversion, (b) cognitive biases and (c) SRI.

\section{Conscientiousness}

Conscientiousness describes the dependability, trustworthiness, industriousness, and perseverance of an individual (Martins, 2002; McCrae and Costa, 1997). Conscientious individuals are likely to be highly competent, self-disciplined and display active involvement in decision making (Gunkel et al., 2010).

Conscientiousness has been found to be negatively linked to randomness bias (Sadi et al., 2011). This indicates that conscientious investors place less reliance on luck and/or superstitions and are meticulous in researching their investment choices. Their high performance orientation may make them more particular about the type of investments made and risk they are willing to assume. As such, the following hypotheses are posited:

H4(a)-4(c). Conscientiousness exerts a significant influence on (a) risk aversion, (b) cognitive biases and (c) SRI.

\section{Neuroticism}

Neuroticism is a state of emotional instability linked to high anxiety and stress (Migliore, 2011). Neurotic individuals are insecure, moody, hot-tempered and impulsive (McCrae and Costa, 1997). They tend to have a pessimistic outlook. This may impact their willingness to assume risks in investing. Emotionally stable investors are more likely to undertake investments in equity and derivatives (Chitra and Sreedevi, 2011).

Neuroticism among investors has been found to be positively correlated with randomness bias and escalation of commitment (Sadi et al., 2011). Their impulsiveness could cause them to be overly anxious or spontaneous in spending and investing and thus we hypothesise that:

H5(a)-5(c). Neuroticism exerts a significant influence on (a) risk aversion, (b) cognitive biases and (c) SRI. 


\section{Demographics}

\section{Gender}

Previous studies have found that females are less confident and more risk adverse in making investment decisions (Ahmad et al., 2011; Fisher, 2010; Bosner and Lakehal-Ayat, 2008; Graham et al., 2002; Furnham and Okamura, 1999; Smith, 1999a). Women are also found to have less interest in financial matters and tend to be impulsive spenders (Lai, 2010; Furnham and Okamura, 1999). Females also tend to place greater emphasis on trust in their financial advisors (Stendardi et al., 2006). They are also less likely to have short-term savings (Fisher, 2010). On the other hand, males are found to be highly selective of the information. Males tend to utilize more heuristics in decision making (Stendardi et al., 2006; Graham et al., 2002).

However, gender did not significantly influence retirement planning intention in Malaysia ( $\mathrm{Ng}$ et al., 2011). Females have more often been found to favour SRIs in studies outside Malaysia (Junkus and Berry, 2010; Glac, 2009; Nilsson, 2008). This study explores the following hypotheses:

H6(a)-6(c). Gender influences (a) risk aversion, (b) cognitive biases and (c) SRI.

\section{Majors}

Students who have taken a personal finance course have been found to be less inclined towards impulsive buying (Lai, 2010). Business courses may create awareness on risks and type of investments and better equip students to make wiser choices. The following hypotheses are advanced:

H7(a)-7c). Education majors influences (a) risk aversion, (b) cognitive biases and (c) time horizon.

The conceptual framework of the study is shown in Figure 1. Hypotheses $H 1$ to $H 5$ series addresses $R Q 1$ whereas $H 6$ and $H 7$ series addresses $R Q 2$

\section{Research methodology}

\section{Sample design}

The study sample comprises 314 undergraduate students of a Business School located in Klang Valley, Malaysia. Respondents were asked to complete an anonymous and voluntary survey questionnaire. This is in line with previous studies which employed student samples in investigating financial decision frames including Glac (2009), Mayfield et al. (2008), Cudmore et al. (2010) and Troisi et al. (2006).

\section{Measurement assessment}

The independent variables for the study are the Big 5 Personality Trait dimensions comprising extraversion (EXTRA), openness (OPEN), agreeableness (AGREE), conscientiousness (CONSC) and neuroticism (NEURO) as well as demographic factors (GENDER and MAJORS). The items for the Big 5 Personality Trait Dimension were adapted from McCrae and Costa (1997).

The dependent variables of the study are risk aversion (RISK), cognitive bias (C_BIAS) and socially responsible investment (SRI). The items for RISK, Savings, Fixed deposits, government mutual funds and government bonds were viewed as less risky instruments as compared to capital guaranteed mutual funds, gold and foreign exchange investments. The items for the constructs of C_BIAS and SRI developed for this study based on concepts derived from the literature. The Likert Scale was used.

Reliability is determined using the threshold Cronbach Alpha. Validity is determined using Exploratory Factor Analysis (EFA). The Principal Component extraction method and the Direct Oblimin rotation method are used. The factor loading threshold of 0.50 is to determine valid items. 


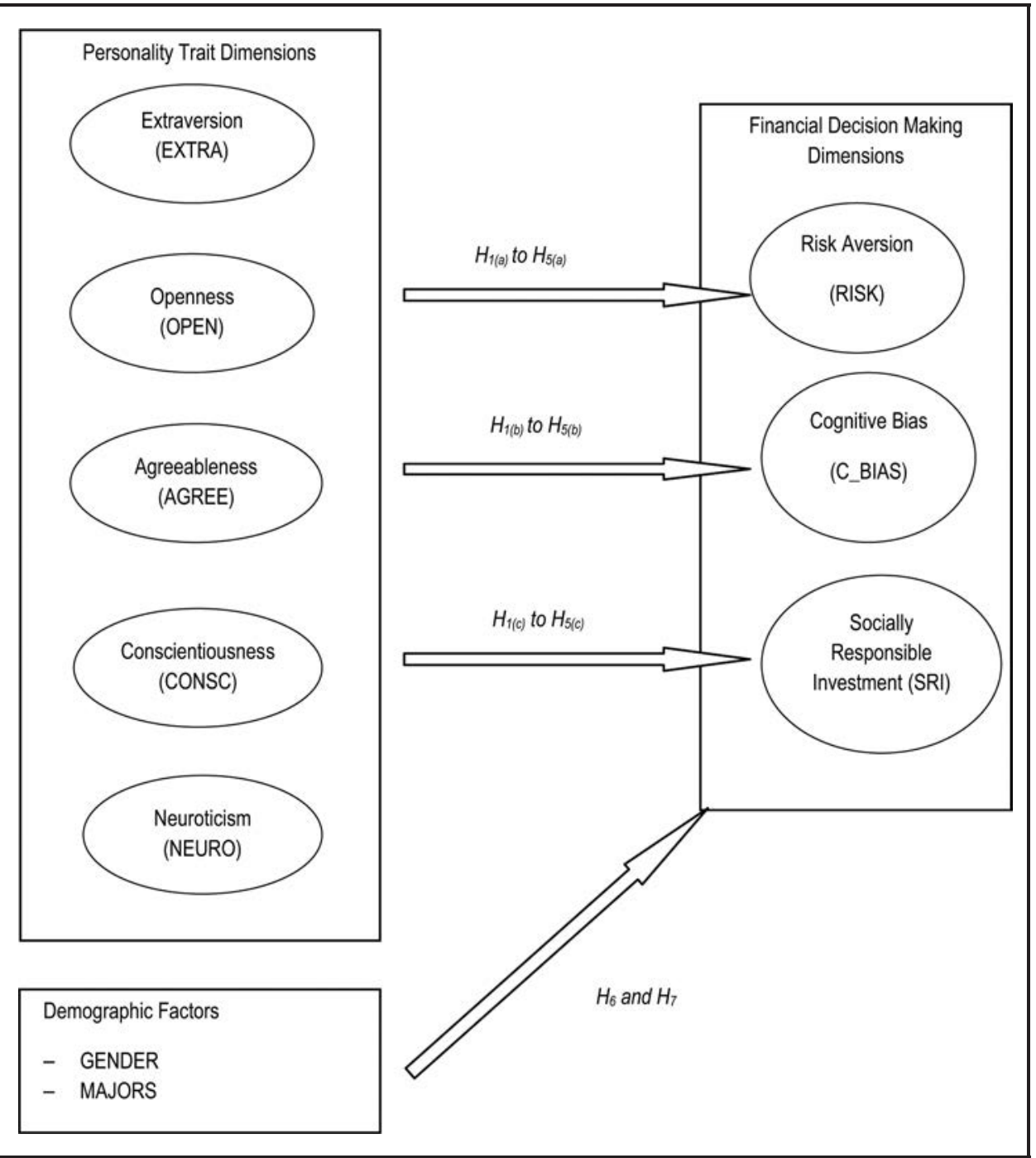

\section{Hypotheses testing}

Hypotheses testing is conducted using IBM SPSS 19. In order to investigate the influence of the Big 5 Personality Traits on RISK (H1(a) to H1(c)), C_BIAS (H2(a) to H2(c)) and SRI(H3(a) to $H 3(c)$ ), the Multiple Linear Regression method is used. To test whether RISK, C_BIAS and SRI differ by GENDER and MAJOR respectively, independent sample T-tests are employed.

\section{Findings}

The majority of the respondents of the study were females (51.1 per cent). Marketing and Management majors constituted 52.3 per cent of the respondents while Accounting and Finance Majors comprised 47.7 per cent.

\section{Validity and reliability}

The Kaiser Meyer- Olkin Measure of Sample Adequacy (KMO) was 0.84 and the Bartlett's Test of Sphericity yielded a Chi-Square of 4,042.41 ( $\mathrm{df}=496 ; p<0.05$ ) satisfying the assumptions for EFA. All the five personality trait dimensions have Eigenvalues of above 1 and are valid. The Cronbach's Alpha for EXTRO, CONSC, NEURO, AGREE and OPEN are $0.82,0.83,0.84,0.85$ and 0.77 respectively indicating their reliability (Nunnally, 1978) 
The Eigenvalues for the dependent constructs (RISK, C_BIAS and SRI) are above 1. The $\mathrm{KMO}$ was 0.82 and the Batlett's Test had a Chi-Square of 2,175.53 ( $\mathrm{df}=105 ; p<0.05$ ). The Cronbach's Alpha for RISK, C_BIAS and SRI are $0.91,0.82$ and 0.82 respectively (Nunnally, 1978).

\section{Influence of personality traits on RISK}

Table I indicates that only CONSC has a significant influence on RISK $(F=2.118 ; p<0.05)$. As such, $\mathrm{H}_{4}(\mathrm{a})$ is supported. Although $\mathrm{H3}(\mathrm{a}), \mathrm{H} 4(\mathrm{a})$ and $\mathrm{H} 5(\mathrm{a})$ are non-significant, EXTRA, AGREE and NEURO has a negative relationship with RISK. Similarly, H2(a) is not supported. OPEN is not significant but has a positive relationship with RISK.

\section{Influence of personality traits on $C_{-} B I A S$}

Only OPEN has a significant positive significant relationship with C_BIAS ( $F=4.215$; $p<0.05)$. $H 2(b)$ is supported. Even though $H 1(b)$ is not significant, EXTRO has a negative relationship with C_BIAS. AGREE and CONSC. NEURO has a positive relationship with C_BIAS but non-significant.

\section{Influence of personality traits on SRI}

In terms of SRI, only AGREE has a significant positive influence ( $F=4.230 ; p<0.05)$. H3(c) is supported. $H_{3}(a), H 3(b), H 3(d)$ and $H 3(e)$ are not supported. EXTRO and OPEN has a positive relationship whereas CONSC and NEURO have a negative relationship with SRI.

\section{Influence of GENDER and MAJORS on RISK, C_BIAS and SRI}

In terms of GENDER, Table II indicates that the difference in means between male and female were not significant. As such, $H 6(a), H 6(b)$ and $H 6(c)$ are not supported. Even so,

\section{Table I Results of hypotheses testing}

\begin{tabular}{|c|c|c|c|c|c|c|c|c|}
\hline Dependent variables & Constant & $\begin{array}{c}\text { Extroversion } \\
(\text { EXTRO) }\end{array}$ & $\begin{array}{l}\text { Inde } \\
\text { Openness } \\
\text { (OPEN) }\end{array}$ & $\begin{array}{l}\text { pendent variable } \\
\text { Agreeableness } \\
\text { (AGREE) }\end{array}$ & $\begin{array}{l}\text { Conscientiousness } \\
\text { (CONSC) }\end{array}$ & $\begin{array}{l}\text { Neuroticism } \\
\text { (NEURO) }\end{array}$ & $R^{2}$ & $\mathrm{~F}$ \\
\hline Risk aversion (RISK) & $4.983^{\star *}$ & -0.006 & 0.003 & -0.005 & $0.064^{\star *}$ & -0.041 & 0.036 & $2.118^{*}$ \\
\hline $\begin{array}{l}\text { Cognitive bias } \\
\text { (C_BIAS) }\end{array}$ & $11.877^{\star *}$ & -0.036 & $0.359^{\star *}$ & 0.076 & 0.053 & 0.060 & 0.072 & $4.215^{\star *}$ \\
\hline $\begin{array}{l}\text { Socially responsible } \\
\text { investments (SRI) }\end{array}$ & $17.812^{\star \star}$ & 0.045 & 0.103 & $0.258^{\star *}$ & -0.038 & -0.013 & 0.071 & $4.230^{* *}$ \\
\hline
\end{tabular}

Table II Results of T-tests on GENDER and MAJORS

\begin{tabular}{|c|c|c|c|c|c|c|c|}
\hline & & $\mathrm{n}$ & Mean & Std. deviation & $\mathrm{t}$ & $d f$ & $\mathrm{p}$-value (2-tailed) \\
\hline \multicolumn{8}{|l|}{ Gender } \\
\hline \multirow[t]{2}{*}{ RISK } & Female & 156 & 6.0769 & 1.73963 & 0.221 & 304 & 0.825 \\
\hline & Male & 150 & 6.0333 & 1.71224 & & & \\
\hline \multirow[t]{2}{*}{ C_BIAS } & Female & 153 & 16.8039 & 3.86628 & -0.726 & 295 & 0.469 \\
\hline & Male & 144 & 17.1458 & 4.25411 & & & \\
\hline \multirow[t]{2}{*}{ SRI } & Female & 157 & 26.5924 & 4.21833 & 0.122 & 0.802 & 0.517 \\
\hline & Male & 148 & 25.7905 & 4.79974 & & & \\
\hline \multicolumn{8}{|l|}{ Course } \\
\hline \multirow[t]{2}{*}{ RISK } & Accounting \& Finance & 131 & 6.1756 & 1.75184 & 0.583 & 275 & 0.560 \\
\hline & Marketing and Management & 146 & 6.0548 & 1.69291 & & & \\
\hline \multirow[t]{2}{*}{ C_BIAS } & Accounting \& Finance & 128 & 17.0391 & 4.02238 & -0.050 & 267 & 0.960 \\
\hline & Marketing and Management & 141 & 17.0638 & 4.13213 & & & \\
\hline \multirow[t]{2}{*}{ SRI } & Accounting \& Finance & 132 & 26.3636 & 4.52014 & 0.411 & 274.0 & 0.681 \\
\hline & Marketing and Management & 144 & 26.1458 & 4.27706 & & & \\
\hline
\end{tabular}


females had a higher mean in RISK and SRI compared to males. Males had a higher mean in C_BIAS.

In terms of MAJORS, the differences in means of RISK, C_BIAS and SRI respectively were not significant between Accounting and Finance and Marketing and Management major groups. However, Accounting and Finance majors showed higher means in RISK and SRI. Marketing and Management majors yielded higher means in C_BIAS.

\section{Discussion and implications of the study}

This study suggests that personality traits of conscientiousness, openness and agreeableness dominate financial decision making. There appears to be preferred personality trait used when making financial decisions involving risk aversion, heuristics and socially responsible investment criteria.

Assessment of risk involves expectations of return, competence and knowledge in financial analysis. Risk adverse individuals are more likely to be rational thinkers who are conscientious about the need to achieve their financial goals (Hanlon, 2000). Although insignificant, the negative relationship between extroversion and neuroticism towards risk aversion in this study suggests the preference towards a greater rational approach in the evaluation of risk. The non-significance of the other dimensions of personality (openness and agreeableness) towards risk aversion lends support to the existence of other financial decision frames that are less than rational (Krishnan and Beena, 2009).

On the other hand, this study also found that the openness trait positively influences the use of heuristics. Openness in individuals promotes greater willingness to embrace unconventional rules of thumb prescribed in financial decision making. While these solutions may be suboptimal, they are acceptable pending further analysis (Maule and Hodgkinson, 2002). Previous research have also found that accounting experts rely more on rules of thumb and established performance benchmarks rather than repetitive analysis in decision making (Smith, 1999a).

This study also found that SRI is significantly positively influenced by agreeableness. This can be explained by the need for consensus in promoting effective pro-social behaviour (Nilsson, 2008). Agreeableness may compensate for uncertainties and in satisfying the moral conscience of individuals when selecting SRI (McLachlan and Gardner, 2004). On the other hand, conscientiousness and neuroticism exhibited a non-significant negative influence. This seems to suggest that individuals apply a different decision frame in evaluating SRI, one that is more based on emotional and moral intelligence rather than merely rational.

In terms of gender and course majors the relationships to financial decision making was found to be insignificant. Even so, the study found that females tended to be more risk adverse and were more willing to subscribe to SRI) and that males relied more on cognitive biases corroborating previous studies (Junkus and Berry, 2010; Nilsson, 2008; Bosner and Lakehal-Ayat, 2008; Graham et al., 2002; Smith, 1999b). The study also found that Accounting and Finance Majors tended to be more risk adverse and subscribe to SRI compared with Marketing and Management Majors. This could be attributable to the exposure of Accounting and Finance students to topics concerning management of risk and return as well as types of investments in their curriculum. On the other hand, marketing and management students may use simplifying rules of thumb to cope with the complexities and information overload in financial analysis to guide their decisions.

\section{Financial planning}

Financial planners need to understand that rationality and personality influence financial decision making. Understanding the link between personality traits and financial decision making will assist financial planners in tailoring products and services to better suit the needs of their potential clients (DeBondt et al., 2010; Holland, 1997). While the financial planning thought process is often tacit, personality traits are more susceptible to observation 
in social situations. This study clearly shows that specific personality dimensions appear to guide specific individual preference in decision making. Thus, to better communicate better with Generation Y clientele, financial planners may need to supplement their existing technical competence with training in areas such as emotional and social intelligence to better understand human personality (Vitt, 2004).

\section{Consumer behaviour and financial institutions}

Understanding consumers' personality and decision making styles may enable financial institutions to better target their marketing efforts. Financial decision making criteria in selection of checking accounts are not always rationally oriented (such as fees charges or product characteristics) but on other criterion (such as convenience and personal relationships). Consumers have been known to apply trade-offs and preferential attribution criteria to facilitate their choice in this area (Lee and Marlowe, 2003). Churning of consumers is also costly for financial institutions and retention efforts can be enhanced by tapping into a greater appreciation of consumer personality.

Understanding the significance of dominant personality traits in financial decision making may also assist bank personnel/officers in better evaluating consumer characteristics prior to granting of loans and/or approval of credit card facilities. Besides, personality traits can be an important source of non-discriminatory information. There may be an avenue for academics and practitioners to collaborate in establishing personality measurement instruments for the banking industry.

\section{Personality and business education}

While psychology degrees offered in Malaysia often include at least a module on Psychology in Business, the focus is very much on the clinical aspects. However, there is very little emphasis of psychology and personality within Business Degree programs in Malaysia.

Financial decisions are made by idiosyncratic human beings. This study emphasises the need to develop an awareness of personality in understanding financial decision making frames. Therefore, it is important to include the study of human psychology in business education in subjects such as personal financial planning. Finance Degree modules often have a high emphasis on technical and quantitative aspects of decision making. In line with the findings of this study, we would strongly advocate the inclusion of at least a behavioural finance module into Finance Degree programs to provide students a more complete appreciation of financial decision making.

\section{Further research}

This study employed a sample of undergraduate respondents which limits the population generalizability. Future research should extend this to different cohorts of individuals including working adults and retirees. The mediating influences of personality and moderating influences of demographic factors such as education level, age and religiousity should also be explored to better target potential investors and fulfill their financial goals

\section{Conclusion}

This study indicates that specific personality traits namely consciensciousness, openness and agreeableness have a significant influence on risk aversion, cognitive biases and socially responsible investing dimensions of financial decision making respectively. The influence of personality traits outweighs demographic factors such as gender and course majors

Within constraints of incomplete information, uncertainty and limited competencies, individuals often make financial decisions with bounded rationality. This study adds to this knowledge by suggesting that within bounded rationality situations, being aware of an individual's personality biases will enable one to understand and evaluate his/her financial decisions to make better choices. Personality may be more easily and faster deciphered in 
social situations than fostering the development of trust. In line with the findings, this study suggests that personality traits may provide a gateway into further understanding the tacit financial decision making preferences of clients. As such, more effective communication and knowledge transfer can be achieved by observation of the personality traits of clients in the area of financial planning as well as in banking relationships and operations. It is also increasingly relevant to introduce behavioural finance modules in Finance Degree programs in Malaysia.

\section{References}

Ackert, L.F., Church, B.K. and Deaves, R. (2003), "Emotion and financial markets", Economic ReviewFederal Reserve Bank of Atlanta, Vol. 88 No. 2, pp. 33-41.

Ahmad, A., Safwan, N., Ali, M. and Tabasum, A. (2011), "How demographic characteristics affect the perception of investors about financial risk tolerance", International Journal of Contemporary Research in Business, Vol. 3 No. 2, pp. 412-417.

Ali, S.M. (2011), EPF wish list: Raise retirement age to 60, available at: http://biz.thestar.com.my/news/ story.asp?file $=/ 2011 / 9 / 27 /$ business/9577028\&sec $=$ business (accessed 10 January 2013).

Angel, J.J. and McCabe, D.M. (2010), "The ethics of speculation", Journal of Business Ethics, Vol. 90 No. 3, pp. 277-286.

Baker, H.K. and Nofsinger, N.J.R. (2002), "Psychological biases of investors", Financial Services Review, Vol. 11 No. 2, pp. 97-116.

Barber, B.M. and Odean, T. (1999), "The courage of misguided convictions", Financial Analysts Journal, Vol. 55 No. 6, pp. 41-55.

Bosner, K. and Lakehal-Ayat, M. (2008), "A comparison of risk tolerance and risk capacity among college finance students", Academy of Accounting \& Financial Studies Journal, Vol. 12 No. 1, pp. 67-78.

Chitra, K. and Sreedevi, V.R. (2011), "Does personality traits influence the choice of investment?", The IUP Journal of Behavioural Research, Vol. VIII No. 2, pp. 47-57.

Chong, D. and Druckman, J.N. (2007), "Framing theory", Annual Review of Political Science, Vol. 10, pp. 103-126.

Cudmore, B.A., Patton, J., Ng, K. and McClure, C. (2010), "The millennials and money management", Journal of Management and Marketing Research, Vol. 4 No. 1, pp. 1-28.

DeBondt, W., Forbes, W., Hamalainen, P. and Muragoglu, Y.G. (2010), "What can behavioural finance teach us about finance?", Qualitative Research in Financial Markets, Vol. 2 No. 1, pp. 29-36.

DeBondt, W., Muradoglu, G., Shefrin, H. and Staikouras, S.K. (2008), "Behavioural finance: quo vadis?", Journal of Applied Finance, Vol. 18 No. 2, pp. 7-21.

Diacon, S. (2004), "Investment risk perception: do consumers and advisers agree?', The International Journal of Bank Marketing, Vol. 22 No. 3, pp. 180-198.

Dole, C. and Schroeder, R.G. (2001), "The impact of various factors of personality, job satisfaction and turnover intentions of professional accountants", Managerial Auditing Journal, Vol. 16 No. 4, pp. 234-245.

Fisher, P.J. (2010), "Gender differences in personal savings behaviours", Journal of Financial Counseling and Planning, Vol. 21 No. 1, pp. 14-24.

Furnham, A. (1996), "Attitudinal correlates and demographic predictors of monetary beliefs and behaviours", Journal of Organizational Behaviour, Vol. 17 No. 4, pp. 375-388.

Furnham, A. and Okamura, R. (1999), "Your money or your life: behavioural and emotional predictors of money pathology", Human Relations, Vol. 52 No. 9, pp. 1157-1176.

Gigerenzer, G. and Gaissmaier, W. (2011), "Heuristic decision making", Annual Review of Psychology, Vol. 62 No. 45, pp. 451-482.

Glac, K. (2009), "Understanding the effects of socially responsible investing: the effect of decision frames and trade off options", Journal of Business Ethics, Vol. 87 No. 1, pp. 41-55. 
Graham, J.R., Stendardi, E.J. Jr, Myers, J.K. and Graham, M.J. (2002), "Gender differences in investment strategies: an information processing perspective", International Journal of Bank Marketing, Vol. 20 No. 1, pp. 17-26.

Gunkel, M., Schlaegel, C., Langella, I.A. and Peluchette, J.V. (2010), "Personality and career deciciveness: an international empirical comparison of business students' career planning", Personnel Review, Vol. 39 No. 4, pp. 503-524.

Hanlon, R.P. (2000), "The use of typology in financial planning", Journal of Financial Planning, Vol. 13 No. 7 , pp. 96-112.

Harrington, S. (2003), "Socially responsible investing", Journal of Accountancy, Vol. 195 No. 1, pp. 52-57.

Herbert, S. (2000), "Bounded rationality and social science", Mind \& Society, Vol. 1 No. 1, pp. 25-39.

Holland, C.R. (1997), "What's your money personality?", Business and Economic Review, Vol. 43 No. 4, pp. 28-30.

Hoy, W.K. and Tarter, C.J. (2010), "Swift and smart decision making: heuristics that work", International Journal of Education Mangement, Vol. 24 No. 1, pp. 351-358.

Huhmann, B.A. and McQuitty, S. (2009), "A model of consumer financial literacy", International Journal of Bank Marketing, Vol. 27 No. 4, pp. 270-293.

Hunt, L. (2009), Planning for retirement, The Star Online, 4 April, available at: http://biz.thestar.com.my/ news/story.asp?file =/2009/4/4/business/3618400\&sec $=$ business (accessed 3 January 2012).

Junkus, J.C. and Berry, T.C. (2010), "The demographic profile of socially responsible investors", Managerial Finance, Vol. 36 No. 6, pp. 474-481.

Kahneman, D. (2003), "A psychological perspective on economics", The American Economic Review, Vol. 93 No. 2, pp. 162-168.

Kahneman, D. and Tversky, A. (1979), "Prospect theory: an analysis of decision making under risk", Econometrica, Vol. 47 No. 2, pp. 263-290.

Keil, M., Depledge, G. and Rai, A. (2007), "Escalation: the role of problem recognition and cognitive bias", Decision Science, Vol. 38 No. 3, pp. 391-421.

Krishnan, R. and Beena, F. (2009), "Measurement of conformity to behavior finance concepts and association with individual personality", The IUP Journal of Behavioural Finance, Vol. VI No. 3 \& 4 , pp. $25-40$.

Lai, C. (2010), "How financial attitudes and practices influence impulsive buying behavior of college and university students", Social Behaviour and Personality, Vol. 38 No. 3, pp. 373-380.

Landberg, W. (2003), "Fear, greed and madness of markets", Journal of Accountancy, Vol. 195 No. 4, pp. 79-82.

Leary, M.M., Reilly, M.D. and Brown, F.W. (2009), "A study of personality preferences and emotional intelligence", Leadership and Organization, Vol. 30 No. 5, pp. 421-434.

Lee, J. and Marlowe, J. (2003), "How do consumers choose a financial institution", The International Journal of Bank Marketing, Vol. 21 No. 2, pp. 53-71.

McCrae, R. and Costa, P.T. (1997), "Personality trait structure as a human universal", American Psychologist, Vol. 52 No. 5, pp. 509-516.

McLachlan, J. and Gardner, J. (2004), "A comparison of socially responsible and conventional investors", Journal of Business Ethics, Vol. 52 No. 1, pp. 11-25.

Martins, N. (2002), "A model for managing trust", International Journal of Manpower, Vol. 23 No. 8, pp. 754-769.

Maule, A.J. and Hodgkinson, G.P. (2002), "Heuristics, biases and strategic decision making", The Psychologist, Vol. 15 No. 2, pp. 68-71.

Mayfield, C., Perdue, G. and Wooten, K. (2008), "Investment management and personality type", Financial Services Review, Vol. 17 No. 3, pp. 219-234. 
Migliore, L.A. (2011), "Relation between big five personality traits and Hofstede's cultural dimensions: samples from the USA and India", Cross Cultural Management: An International Journal, Vol. 18 No. 1, pp. 38-54.

Miller, E.M. (1999), Book review: Why Smart People Make Big Mistakes - and How to Correct Them: Lessons from the New Science of Behavioural Economics, Simon \& Schuster, New York, NY.

Ng, T.H., Tay, W.Y., Tan, N.L. and Lim, Y.S. (2011), "Influence of investment experience and demographic factors on retirement planning intention", International Journal of Business and Management, Vol. 6 No. 2, pp. 196-203.

Nilsson, J. (2008), "Investment with a conscience: examining the impact of pro-social attitudes and perceived financial performance and socially responsible investment behavior", Journal of Business Ethics, Vol. 83 No. 2, pp. 307-325.

Nunnally, J.C. (1978), Psychometric Theory, 2nd ed., McGraw-Hill, New York, NY.

Olsen, R.A. (1998), "Behavioural finance and its implication for stock-price volatility", Financial Analysts Journal, Vol. 54 No. 2, pp. 10-18.

Olsen, R.A. (2010), "Toward a theory of behavioural finance: implications from the natural sciences", Qualitative Research in Financial Markets, Vol. 2 No. 2, pp. 100-128.

PriceWaterhouseCoopers (2009), Malaysia's Gen Y Unplugged, available at: www.pwc.com/en_my/my/ assets/publications/gen-y.pdf (accessed 10 January 2013).

Rabin, M. and Thaler, R.H. (2001), "Anomalies: risk aversion", Journal of Economic Perspectives, Vol. 15 No. 1, pp. 219-232.

Robie, C., Brown, D.J. and Bly, P.R. (2005), "The big five in USA and Japan", Journal of Management Development, Vol. 24 No. 8, pp. 720-737.

Sadi, R., Asl, H.G., Rostami, M.R. and Gholipour, F. (2011), "Behavioural finance: the explanation of investors' personality and perceptual biases effects on financial decisions", International Journal of Economics and Finance, Vol. 3 No. 5, pp. 234-241.

Shiller, R.J. (2002), "Bubbles, human judgment and expert opinion”, Financial Analyst Journal, Vol. 58 No. 3, pp. 18-26.

Smith, A.L. and Harvey, T.W. (2011), "Test of a theory: an empirical examination of the changing nature of investor behavior", Journal of Management Policy and Practice, Vol. 12 No. 3, pp. 49-68.

Smith, M. (1999a), "Personality issues and their impact on accounting and auditing", Managerial Audit Journal, Vol. 14 No. 9, pp. 453-460.

Smith, M. (1999b), "Gender, cognitive style, personality and management decision making", Management Accounting, Vol. 77 No. 7, pp. 18-22.

Statman, M. (1999), "Behaviorial finance: past battles and future engagements", Financial Analysts Journal, Vol. 55 No. 6, pp. 18-26.

Stendardi, E.J., Graham, J.F. and O'Reilly, M. (2006), "The impact of gender on the personal financial planning process: should financial advisors tailor their process to the gender of their client", Humanomics, Vol. 22 No. 4, pp. 223-238.

Tang, T.L., Chen, Y. and Sutarso, T. (2008), "Bad apples in bad (business) barrels", Management Decision, Vol. 46 No. 2, pp. 243-263.

Thaler, R.H. and Sustein, C.R. (2009), Nudge: Improving Decisions about Health, Wealth and Happiness, Penguin Books, New York, NY.

Troisi, J.D., Christopher, A.N. and Marek, P. (2006), "Materialism and money spending disposition as predictors of economic and personality variables", North American Journal of Psychology, Vol. 8 No. 3, pp. 421-436.

Vitt, L.A. (2004), "Consumers' financial decisions and psychology of values", Journal of Financial Service Professionals, Vol. 58 No. 6, pp. 68-77.

Williams, K.C., Page, R.A., Petrosky, A.R. and Hernandez, E.H. (2010), "Multi-generational marketing: descriptions, characteristics, lifestyles and attitudes", Journal of Applied Business and Economics, Vol. 11 No. 2, pp. 21-37. 


\section{About the authors}

Dr Joyce K.H. Nga is currently a Senior Lecturer and the Head of the Finance Cluster at Taylor's Business School. Prior to this, she has worked as an Auditor for KPMG, Malaysia, as well as Financial Controller for a range of companies in the hospitality industry in Malaysia. She has lectured in areas such as corporate financial analysis, corporate finance: theory and practice, business ethics and values, financial reporting and business research methods. Dr Nga's areas of interest are in corporate social responsibility, business education, financial planning, social entrepreneurship and business ethics. Joyce K.H. Nga is the corresponding author and can be contacted at: KoeHwee.Nga@taylor's.edu.my

Leong Ken Yien is currently a Finance Lecturer at Sunway University Business School. Prior to this, she has worked in one of the anchor banks in Malaysia, specializing in share margin financing at the branch level, and subsequently in credit control and other monitoring roles at the headquarter level. In past years, Leong has lectured in areas including financial management, principles of banking and finance, corporate finance, investment and portfolio management, and other management subjects. Her research interests are financial planning, behavioural finance, entrepreneurship and planning, and education.

To purchase reprints of this article please e-mail: reprints@emeraldinsight.com Or visit our web site for further details: www.emeraldinsight.com/reprints 